\title{
Transnational Social Mobility Strategies and Quality of Work Among Latin-American Women Sex Workers in Spain
}

\author{
Laura Oso \\ Universidade da Coruña, Spain \\ laura.oso@udc.es
}

Reference of the publication:

Sociological Research Online, 21 (4), 11 DOI: 10.5153/sro.4129 Received: 23 Jun 2016 | Accepted: 28 Oct 2016 | Published: 30 Nov 2016

\begin{abstract}
The aim of this article is to analyse the quality of work of two of the main types of female sex work in Spain (clubs and in-call flats). In order to do so I will focus on the following working dimensions: wages, power relations, skills, alienation, health, violence, work life and stigma. Firstly, the article seeks to highlight the structural factors that condition the quality of work of Latin American female sex workers in Spain. These factors are closely connected to policies regarding migration and sex work, which foment irregular work arrangements (undocumented migrants and informal workers). Secondly, I analyse entry formats (indebted or autonomous migration) and how they impact on working conditions. Thirdly, the article considers the migrant women's work choices and the resulting living and working conditions they may encounter. I intend to show that Latin American women sex workers in Spain might opt for a certain type of work within the context of strategic decisions, as linked to their migratory and social mobility projects. These decisions have a family and a transnational scope (country of origin, country of destination). The analysis presented is based on qualitative fieldwork (semi-structured interviews) carried out in Galicia (north-west Spain).
\end{abstract}

Keywords: Sex Work, Prostitution, Gender, Migration, Quality of Work, Latin-American Women, Transnational

\section{Introduction: Beyond trafficked women, the study of quality of work}

Recent decades have witnessed major growth in the international sex industry, linked to migratory flows within the framework of global capitalism (Lim 1998; Sassen 2003; Bernstein 2008; Cabezas 2009). In general terms, a significant proportion of the literature on this subject has focused on the human trafficking of migrant women for sexual exploitation purposes, emphasising their status as victims in the international sex industry (IOM 1995, 1996; Slrobanek et al. 1997; Stone \& Vandenberg 1999; Farr 2005). In the late 1990s and the early years of the 21st century several authors began to question the 'trafficking perspective'. Early 
works adopting this line include those by Doezema (1998), Kamala Kempadoo (2005), Laura Agustín (2007), Ronald Weitzer (2007) and Sophie Day (2009). Although there are indeed terrible cases of migrant women who have been duped and traded against their will, numerous studies confirm that large numbers of migrant women in the European sex industry are aware that they will be selling sex (see, for instance, Mai 2001; Oso 2003; Piscitelli 2008, 2013; Spanger 2010; López Riopedre 2014, 2015;Plambech 2014). Nevertheless, less attention has been paid to the study of women sex workers' quality of work, within the framework of migrant life and migratory strategies.

On the other hand, as pointed out by Muñoz de Bustillo et al., in recent years the 'quality of work' issue has attracted growing scientific and political interest. Indeed, it has captured the attention of a number of international organisations. This increasing interest is attributable to the claim that 'the quality of working life is a key element in quality-of-life' (Muñoz de Bustillo et al. 2011: 448), where 'job quality' is understood to be 'the characteristics of work and employment that affect the wellbeing of the worker' (Muñoz de Bustillo et al. 2011: 460). However, this analytical approach has not been widely applied to informal economic sectors, with the exception of a small number of research projects (Tony Avirgan et al. 2005 among others), and sex work has been practically ignored within the literature in this field. As highlighted by Adriaenssens and Hendrickx (2016), studies on sex work have mainly focused on the occupational health risks of this mode of working (Prüss-Ustün et al. 2013; McGrath-Lone et al. 2014, among others, quoted in Adriaenssens \& Hendrickx 2016). Indeed, the issue has been studied mainly by public health scholars, who have tended not to address other aspects, such as the institutional organisation of employment relations and the quality of work dimensions of sex work. Such sociological considerations have tended to be relegated to the background. As these authors point out, 'this literature makes use predominantly of survey data (next to test results in healthcare)' (Adriaenssens \& Hendrickx 2016).

This text aims to contribute to the aforementioned debate in the literature in three ways. Firstly, moving beyond the trafficking debate to the issue of migration and sex work, it studies the quality of work of LatinAmerican women sex workers in Spain from a sociological perspective. It argues that there are multiple sources of and considerable variation in the quality of sex work. The article seeks to define the structural factors that condition the quality of work of migrant women sex workers in Spain, that are closely linked to policies affecting migration and sex work, which foment irregular work arrangements (undocumented migrants and informal workers). It also analyses how the migrant entry mechanisms (autonomous or indebted women) impact on the quality of work. Finally it posits that Latin American women sex workers make decisions wherein the quality of work is not the sole element they take into account. The decisions concerning the type of work they might opt for (and consequently the working and living conditions they might encounter) should be understood within the framework of the more global social mobility strategies migrants adopt. These strategies extend to family members, who often remain behind in the country of origin. In this sense, I intend to show that Latin-American women sex workers in Spain might opt for a certain type of work, within the context of strategic decisions, linked to their migratory and social mobility projects. These decisions have an impact on women's living and working conditions. Migrant women therefore choose between opportunity sets (even though they may be limited), as 
shaped by policy and the structure of the market, that are in the background with respect to their life strategies.

Secondly, the article is intended to contribute to scientific debate on quality of work, providing data for a segment of the labour market which, apart from the evident occupational health risks involved, has largely been overlooked in the literature. I will thereby show how quality of work should be analysed within the context of the migratory and social mobility strategies of Latin-American female sex workers. Indeed, as Muñoz de Bustillo et al. (2011) explain, 'the impact of a given job on workers' wellbeing depends on the interplay of the characteristics with the existing welfare arrangements and supporting role played by the family' (457).

Thirdly, the approach to the quality of work issue will be of a qualitative nature, providing a more finelynuanced insight into the meaning people attach to certain aspects of work than quantitative (survey) research can offer. Indeed, the use of qualitative interviews provides a more in-depth vision of the subjective ways in which female migrant sex workers assess quality of work in accordance with their own migratory and social mobility strategies. It is precisely this aspect that I wish to draw attention to, as it will reveal that for some women a certain type of work is better suited to their interests, due to the greater earning potential involved, in line with a migratory strategy that seeks to maximise savings, allowing them to return to their countries of origin sooner. In contrast, other women consider that this type of work implies a strong degree of subordination, and therefore see it as an undesirable option. It is these subjective aspects that I wish to focus on, shedding light on the varying conceptions of quality of work in accordance with the migratory and social mobility strategies of Latin-American female sex workers. I therefore aim to overcome the limitations of quantitative research, as reported by Muñoz de Bustillo et al. (2011), whereby surveys fail to provide a context for the reasons underlying workers' appraisal of their quality of work (Muñoz de Bustillo et al. 2011). In this sense, this study aims to consider the issue of contextualisation in depth. It provides an analysis of the subjectivities of social actors regarding quality of work, as part of their overall life strategies in general, and migratory strategies in particular. It analyses how these strategies determine their action choices and opinions regarding which types of work are 'better' or 'worse'.

Having presented the methodology, the article describes the working and living conditions of two of the main types of sex work in Spain: in clubs and in-call flats, providing an insight into how migrant women rate the quality of work in these two forms of employment. This initial section ends with a table summarising the various working conditions in each type of employment, in accordance with a series of working dimensions that have been identified. It reveals that the working and living conditions in clubs are much harsher than in the flats, even though the earnings and potential for saving are far higher. The article then goes on to explain the extent to which policies regarding migration and sex work have an impact on the quality of work of migrant women in Spain, generating a large number of undocumented migrants and leading to the worsening of immigrant sex workers' working and living conditions. It also explains how the means of entrance (indebted or autonomous migration) impact on working conditions. Finally, the article reveals how the decision that migrant women take to choose the harshest type of sex work (living in the club and rotating in the plaza system) is articulated with respect to the migratory and social mobility strategies of migrants. This can explain why 
women, freed from the repayment of a debt, opt to work in clubs under the plaza system, even though this involves accepting working conditions that are far worse. The fact of being subject to the pressures of sending remittances to their country of origin, or having a migratory project based on saving up enough money to return as soon as possible, might explain this type of decision which impacts directly on women's working and living conditions.

\section{Methodology and the socioeconomic profile of informants}

The analysis presented is based on the results of qualitative fieldwork carried out with Latin American women sex workers in Galicia (Spain) within the framework of three studies (Oso 2000, 2001a, 2001b) and their updating with qualitative data carried out in 2014 and 2015. Individual and group interviews were conducted in 2000 and 2001 with 50 women sex workers (34 Colombians, six Brazilians, six Ecuadorians, two Dominicans, one Argentinean, and one Venezuelan); six business owners; 11 clients of brothels and in-call flats; and 15 key informants in contact with sex workers (NGO workers, doctors, and so on). In total 82 people were interviewed. The fieldwork was carried out in Galicia (north-west Spain), in the provinces of $A$ Coruña, Pontevedra and Lugo. Between 2014 and 2015 I conducted a further seven interviews with migrant women who had worked in the sex industry and with key informants.

The initial form of contact was via NGOs working with the immigrant population through offering them legal advice. These early interviews had a snowball effect, enabling me to contact further informants. Through a number of these informants (as well as the person in charge of editing the classified advertisements in one of Galicia's leading daily newspapers), I had access to four in-call flats in A Coruña and Pontevedra. I was able to interview the owners and workers, as well as observe their daily habits, accompanying the women whilst they prepared meals, hung out the washing, put on their makeup and did their hair, answered phone calls or watched soap operas on television, and so on. Being a female researcher made access to these flats easier, as they are essentially female environments, whereas in the case of the clubs (run by men), access proved more difficult, forcing me eventually to approach immigrant women working in clubs through contact with a country doctor. These interviews were the most distressing, as several of the informants had only recently arrived and were isolated and in debt, which made them less trusting and fearful when interviewed. Furthermore, the fact that they work at night and have very little free time meant that the interviews were extremely difficult to organise.

Most of the interviews were held in the informants' places of residence (shared rented flats) or in their workplace (in the case of in-call flats), although some were also held in public places (bars or coffee shops). Half of the total number of interviews were recorded and on the remaining occasions notes were taken during the interview with the information later reconstructed. The interviews lasted an average of one and a half to two hours.

A large number of the women I interviewed were the heads of their household, single mothers, or separated or divorced women, whose children had remained in their country of origin when they travelled to Spain. These women usually have an average level of education; indeed, most have completed secondary education or some kind of vocational training, whilst others have completed years of study at university. The women I interviewed had entered Spain as tourists on a three month visa, later opting to remain in the country as undocumented 
residents for long periods of time. At the time of interview around two thirds of the women had managed to legalise their status in Spain, and the number of undocumented women formed a minority. It was harder to persuade newly-arrived and undocumented women to agree to be interviewed and therefore I had greater access to those women who had managed to legalise their status.

\section{Quality of work among sex work in Spain: Clubs and in-call flats}

\section{Clubs: Higher earnings but harsh working conditions}

The fieldwork carried out indicates that street sex work has gradually disappeared from the large Galician cities, where it was traditionally concentrated in certain neighbourhoods. It has been replaced by an increasingly large number of clubs. These bars, mainly located on the main roads or on the outskirts of cities, vary in size. Some are small businesses with just a few women (3-5), whilst others are of medium size and have a larger number of workers (10-15). The largest bars may employ up to 50 women. In Galicia, the majority of workers in these clubs are migrants. Typically, the clubs are owned by Spanish men who run them either on their own or with a partner. Several club owners in Galicia have married Latin American women, who then help their husbands to run the business. Setting up clubs of this type requires a considerable financial outlay, and it is therefore difficult for sex workers to invest in this kind of business.

Clubs are generally open from five or six in the evening to three or four in the morning. Earnings are normally shared out between the club owner and the women according to a percentage or a system of plazas ('places'). The clubs that work with a percentage method usually take 20 per cent per service. With the plaza system, the woman contacts the club and asks for a certain number of days, guaranteeing that she will work for 21 consecutive days, without a day off. In this system, the club charges the women 40-50 euros for each day she works and the rest she keeps for herself. The plazas are usually large businesses which offer accommodation (rooms) and board for the days the woman spends there. However, some small and medium-sized businesses also have rooms in the club itself or rented apartments in the surrounding towns. The women pay a daily rate for board and lodging. In addition to their earnings per service, the women receive 50 per cent commission on the drinks the clients buy for them in the club, thereby boosting the earnings (wages) of the women who opt for this form of sex work.

A considerable part of club work therefore takes place at the bar, where the women 'butter up' their clients. Each woman naturally has her own ways of 'flirting', but they generally tend to consist of the use of terms of endearment and suggestive poses. This flirting ritual is perceived negatively by some women as a form of submission and humiliation, and a drawback to working in clubs. In contrast, some of the informants consider this process to be an advantage, as, regardless of the initial physical impression they make on the client, 'flirting' enables women to use a verbal strategy to attract clients. In this way, their conversational skills will enable them to offset any disadvantages in terms of their physical attractiveness.

Another disadvantage of working in clubs, as perceived by informants, is the competition between the workers, who have to 'fight' one another to get the client, even though there is a 
kind of unspoken agreement between the women during the 'flirting' process. This includes not looking at a client while he is being seduced by a fellow worker unless she is rejected, thus leaving the way open for another woman.

In turn, certain respondents stated that clubs exert stricter controls over their workers, establishing measures such as fines if they spend longer in the room than agreed; meeting clients outside the club, even though they only have a coffee or go for a walk together; or arriving late for work. Some sex workers claimed that some club owners make the women pay for any broken glasses, charging them far more than the actual cost. Apart from cash fines, there are also other types of regulations, which, in the case of the strictest clubs, can be seen as an invasion of the workers' private lives. These include strict recommendations against having a partner or boyfriend and not having relationships with club employees (such as waiters or managers).

This type of sex work enables women to make a considerable amount of money in a relatively short period of time, thereby making it easier for them to save. The women rotate from one business to another, according to the opportunities available; however, it is true that deciding which club to move to also depends on police raids. As a result, the female immigrants choose their destination not only in accordance with the amount of work available, but also based on the likelihood of a police raid (calculating, for instance, the length of time since the police last visited each business). Indeed, police raids are the main disadvantage of clubs, as perceived mainly by undocumented migrant sex workers, as they risk deportation or a serious reduction in their chances of legalising their situation in another sector of employment in the future, if they end up with a police record and expulsion order.

Women working in clubs may reside on the premises, share a flat or live in a boarding house or other kind of residence and only go to the club in the evenings to work. Living on the premises is financially advantageous for some female immigrants. It provides them with board and lodging, and eliminates the costs and difficulties of renting a flat and buying food, thereby increasing their saving capacity. However, despite these financial advantages, working and living conditions for women living in the club are perceived as far harsher, as they are subjected to far stricter controls by the club owners. To this I must also add social isolation, lack of independence, the absence of personal space, and more fights and clashes with other women. The daily routine is entirely work-centred: the women wake up at midday, have a meal and get ready to start their working day (showering and dressing). Frequently their only leisure activity is watching a soap opera on television.

\footnotetext{
When they live in the club and they want to leave, they have to ask permission. If they agree, they give them permission, and if they don't, they don't let them out or they fine them for wanting to leave [...] If they live in the club and feel unwell, they have to go down to work, or pay the fine for not going down. So it's like they take advantage of you more if you live in the club, even though it's a cheap way of living. (Colombian woman working in a club in Galicia)
}

In general, working in clubs, as a resident, simple worker or using the plaza system, brings with it a series of health disadvantages as perceived by informants. These include lack of sleep, alterations to the women's biological rhythm due to the fact that they work at night, as well as eating disorders, as in most clubs women only really have one proper meal a day. Furthermore, the women argue that their health suffers from the effects of working at night in 
settings with poor lighting and an excessive intake of alcohol. Several of the women interviewed claimed that after working 21 consecutive days shut up in such an atmosphere they were unable to stand daylight without sunglasses.

The dual nature of these clubs, offering sex work and alcohol, means that, more often than with other forms of sex work, clients are drunk. The 'night atmosphere' surrounding club sex work also 'attracts drugs', which leads to unfortunate scenes of violence that have a negative impact on working conditions, as stated by sex workers. Moreover, the women interviewed claimed that club clients are less concerned with issues such as personal hygiene (body odour on feet and armpits) than those frequenting in-call flats. This may be related to the more rural environments these businesses tend to be located in, where the population is older.

\footnotetext{
Men up there behave like madmen, passing on stuff, treating you badly. Once, a guy said I looked like his girlfriend who had let him down badly. He paid me, and while we were fucking he said, 'Say "I'm your Estrella"', but I replied 'My name's María'. He went crazy and started hitting me. He grabbed me round the neck and it took the waiter and my boss to get him out of there. (Colombian woman working in a club in Galicia)
}

In short, the working and living conditions in clubs are perceived as extremely harsh, especially for those women who reside in the clubs and work under the plaza rotation system. However, their earning potential is greater, and this option is therefore associated with a saving strategy, as the women can live and work in the clubs without having to spend money on board and lodging. I will now consider the working conditions in the incall flats.

\section{In-call flats: Better quality of work but lower earnings}

Working in in-call flats is a less visible type of employment than street or club sex work. Rented flats situated in discrete areas are used, where various women go to work several hours a day or to spend certain periods of time (in these flats the women can also work 21 day plazas). There may be between three and 15 women in these apartments. They are usually small businesses run by a 'Madame', although some women opt to rent apartments and work there alone or make arrangements with a group of workers and share the expenses. Clients contact the apartment through advertisements on the Internet or in the press. Apartments function on a percentage basis (50 per cent of the earnings from the sex services go to the Madame). Unlike the clubs, these apartments operate 24 hours a day, with the women rotating from apartment to apartment according to the work available.

According to the informants, the main advantage of in-call flats is that they are discrete. Some combine this work with office work, domestic service, and so on. They go to the apartment either in the morning or the afternoon, at fixed times, in order to avoid arousing suspicion in their social environment. The women therefore perceive that the sense of stigma in this type of sex work is less, allowing them to lead a double life, as it is easier for them to conceal their activity than it is for those who work in clubs, which are open spaces where the women are publicly exposed. In the case of the flats, the women can observe the clients before being introduced to them, thereby enabling them to check that they do not know the person and to conceal their identity to a greater degree. 
Other advantages of in-call flats are that there are no police raids, and they offer greater peace of mind and a higher degree of autonomy, as highlighted by informants. Women rest in the lounge while they wait for clients to arrive, watching television, doing their nails and hair together, or writing to their families and doing various types of handicrafts. The women state that they 'feel at home' in the apartment, and wander around the corridors in dressing gowns and slippers, only changing into their 'high heel boots' when the doorbell rings, announcing the arrival of clients. Another advantage of working in apartments, as perceived by workers, is that it is mainly day work (the women are not forced to work until late at night and therefore to alter their biological rhythms) and it does not involve drinking alcohol. Women also consider that the fact that they are not required to carry out the 'flirting' ritual relieves them from a certain degree of stress and the permanently staged atmosphere of the clubs, working with drinks at the bar.

In the flats the diet is also better, as the women shop and cook for themselves. In general terms the timetable in the apartments is flexible; the women may choose to spend the whole day there or just a few hours, and they are free to go out and do errands and so on. Furthermore, the 'standard' of clients in these apartments is usually perceived by workers as higher: they are people who treat women better, are looking for discretion and, unlike in clubs, rarely arrive drunk or intoxicated with drugs.

However, earnings in general are lower than for those who work in clubs. The price of a minimum service (20 minutes) in a club or an apartment is around the same throughout Galicia (40-60 euros), but in flats the final wages are lower, as there are fewer clients and shorter working hours. Furthermore, there is no commission on drinks, and there is a higher fee for intermediaries ( 50 per cent for the Madame). The financial accumulation is also lower in in-call flats, because many of the women working in apartments have their own home, which implies additional expenses (payment of housing and food). However, the permanent rotation or plaza system also exists in the flats, and some women travel around Spain, living temporarily in the in-call flats.

Unlike the clubs, where the majority of workers are immigrants, around half of the workers in in-call flats are Spanish women (due mostly to flexibility and less visibility). This number has risen considerably in recent years due to the economic crisis (for a more in-depth analysis of the impact of the economic crisis see López Riopedre 2013, 2015). In-call flats are also an occupational strategy employed by more settled female immigrants: they have a permanent home, have reunited with their children, have a more stable partner, carry out other types of work outside the sex industry and use these flats as a means of supplementing their income.

The working conditions discussed above are summarised in the following table, sorted by clubs (under a more intensive work system, where the women live in the clubs and rotate in accordance with the plaza system) and in-call flats. The table includes aspects regarding the quality of the work carried out, as described in 'quality of work' literature (Muñoz de Bustillo et al. 2011). The dimensions include those considered most appropriate to the nature of sex work, namely wages, power relations, skills, alienation, health, violence and work life. Stigma has also been included as a further consideration, specific to sex work, although traditionally it is not addressed within scientific literature regarding quality of work. 
Table 1. Dimensions of quality of work: Subjectivities among Latin American women sex workers in Galicia

\begin{tabular}{|c|c|c|}
\hline Dimensions of Quality of Work & $\begin{array}{l}\text { Clubs } \\
\text { (living in the club-plaza system) }\end{array}$ & In-call flats \\
\hline Wages & $\begin{array}{l}\text {-Price of a minimum service }(40-60 \\
\text { euros) but higher wages as: more clients } \\
\text { and hours of work, earnings from drinks } \\
\text { and more opportunity to save (no } \\
\text { accommodation costs when working in } \\
\text { the plaza system) }\end{array}$ & $\begin{array}{l}\text { Price of a minimum service ( } 40-60 \text { euros) } \\
\text { but lower wages: fewer clients, shorter } \\
\text { working hours, no commission on drinks, } \\
\text { more expenses (accommodation), } \\
\text { higher fees for intermediaries ( } 50 \text { per } \\
\text { cent for the Madame) }\end{array}$ \\
\hline Power relations & $\begin{array}{l}\text { - More dependency on male owners of } \\
\text { clubs } \\
\text { - Greater submission and humiliation } \\
\text { before the client during the 'flirting' } \\
\text { ritual }\end{array}$ & $\begin{array}{l}\text {-Less dependency - more equal } \\
\text { relationships with flat owners } \\
\text { - 'Flirting' ritual is not needed }\end{array}$ \\
\hline Skills & $\begin{array}{l}\text { - Importance of the capacity for 'chit- } \\
\text { chat' - not merely physical appearance } \\
\text { (flirting ritual) }\end{array}$ & Physical appearance is a priority \\
\hline Alienation & $\begin{array}{l}\text { - Social isolation } \\
\text { - Lack of independence } \\
\text { - The non-existence of personal space }\end{array}$ & $\begin{array}{l}\text {-Higher degree of autonomy } \\
\text {-Flexible timetable. } \\
\text {-Freedom to go out to do errands } \\
\text { - More frequently women have their } \\
\text { own home (personal space) }\end{array}$ \\
\hline Health & $\begin{array}{l}\text { - Alcohol (working with drinks) } \\
\text { - More presence of drugs } \\
\text {-Working at night: lack of sleep and } \\
\text { alterations to the women's biological } \\
\text { rhythms } \\
\text { - Eating disorders, } \\
\text { - Atmosphere with poor lighting }\end{array}$ & $\begin{array}{l}\text {-Not working with alcohol (drinks) } \\
\text {-Less presence of drugs } \\
\text {-Mainly day work. Women do not alter } \\
\text { their biological rhythms } \\
\text {-Better diet }\end{array}$ \\
\hline Violence & $\begin{array}{l}\text { - More violence in the rooms with } \\
\text { clients } \\
\text { - More clients that arrive drunk or } \\
\text { intoxicated with drugs } \\
\text { - Competition among workers to obtain } \\
\text { clients } \\
\text { - Police raids }\end{array}$ & $\begin{array}{l}\text { - Less violence in the rooms with clients } \\
\text { - Less competition among sex workers } \\
\text { (the client chooses) } \\
\text { - Clients rarely arrive drunk or } \\
\text { intoxicated with drugs }\end{array}$ \\
\hline Work life & $\begin{array}{l}\text { Difficulty in combining work in clubs } \\
\text { with family life }\end{array}$ & $\begin{array}{l}\text { Possibility of adapting working hours to } \\
\text { life with a partner or family, leading a } \\
\text { 'double life' or combining this work with } \\
\text { another job. }\end{array}$ \\
\hline Stigma & $\begin{array}{l}\text { More stigma, as clubs are public spaces } \\
\text { where the women are visible }\end{array}$ & $\begin{array}{l}\text { Less stigma, more discrete form of work, } \\
\text { easier to conceal identity }\end{array}$ \\
\hline
\end{tabular}

Source: Author's own based on data obtained from fieldwork

However, the quality of work for immigrant women in Spain is equally conditioned by their undocumented status and the debt incurred during the migratory process. Both factors are determined by restrictive policies regulating migration and sex work, as well as by the mechanisms of entrance (indebted and autonomous migration), an issue which is addressed below.

\section{Structural determinants of quality of work and entry mechanisms}

Two major barriers for migrant sex workers in Spain are Spanish immigration policies and existing legislation regulating sex work. The former is responsible for generating a pool of undocumented workers, whilst the latter has created a legal limbo for sex work: although not illegal, it is neither recognised nor regulated as a profession. Police raids to arrest undocumented migrants, affecting brothels in particular, are a major factor in creating feelings of insecurity among sex workers, who live in constant fear of arrest. Undocumented women 
have no rights as citizens and workers, making it more difficult for them to work independently and operate their own businesses. The absence of legal protection also means that migrant women have no choice but to rely for protection on those who view them as a source of profit, namely the owners of brothels. The fact that migrant women are undocumented also makes them afraid to leave brothels and in-call flats, and this isolates them. Brothel owners or managers, as well as clients, often threaten to report the women to the authorities, taking advantage of the isolation and fears of undocumented migrants.

The combination of a restrictive migratory policy and sex work policy in Spain, that fails to provide social and labour protection for sex workers, considerably limits women migrants' chances of securing recognition of their rights. Obtaining work and residence permits for migrants working in recognised sectors (domestic service, the hotel and restaurant trade, and so on) is in itself a complex process, yet for women migrants in the sex industry it is even more difficult. The road to regularising the legal situation is paved with far more difficulties for sex workers (López Riopedre 2013).

Furthermore, the fact that it is impossible to legally channel flows of migrant sex workers leads to a trade in migrants. Sex workers are therefore pushed into migration using intermediaries who see them as a means to personal gain and profit. Entry mechanisms to Spain of migrant women (indebted or autonomous migration) also have an impact on sex workers' quality of work, as will become clear in the following discussion.

\section{Indebted migrants}

Of all the female immigrants interviewed, only three arrived in Spain under false pretences, unaware of the type of work they would be carrying out. Half of the respondents were in debt on arrival in Spain, albeit aware that they would be working in the sex industry. This type of entry mechanism does not involve large networks or mafias, but instead tends to be based essentially on the migratory flow itself: in other words, through social networks woven by the migrants. In Galicia, it is common practice for settled Latin American female immigrants, with a relatively stable legal status, to invest financially in bringing third persons over too (friends, relatives or acquaintances in Latin America). This investment consists of providing them with the money they need for the plane fare and their travel funds (the amount of money required by Spanish border authorities to allow entry as tourists), as well as a letter of invitation and contacts to work in Spain:

Back in Colombia it's your fellow workers who suggest you come over: those that are already here, are working or have worked in the past. A friend says: you'll have to do this kind of work; I'll lend you the money for the trip. Most are married, they talk to you, lend you the money for the trip as well as the money you may need to show in migration. They tell you where the club is. They didn't ask me for any money. Lots of women say they have to pay, but they mean their friends, not the club owners. (Woman who migrated to work in a club)

The size of the debt varies. Among the informants I encountered women whose friends or relatives had lent them the money for the ticket on an interest-free basis, whilst others had incurred a debt that ranged from 2000 to 9000 euros. In these cases, the 'deceit' lay not so much in the type of work involved, but rather in the size of the debt, which in many cases is far higher than the actual cost of the trip. Some of the indebted women I interviewed have a far 
freer and less dependent relationship with the persons who lent them the money, although I did encounter situations of abuse among the indebted Latin American women.

For these women the pressure to repay the debt has a major negative impact on their working and living conditions. They tend to be more isolated and dependent on third persons (who lent them the money). Access to these people is complex (they remain isolated in the clubs), and fear makes them reluctant to contact organisations offering support for immigrants and sex workers. These women have to work intensely in order to pay off their debt, dealing with a large number of clients per day and with few or no days off, even when they are ill. Financial necessity caused by debt repayments pushes some women to accept clients who do not wish to use a condom (due to competition for the relatively low number of clients), putting their health at risk. This economic pressure and the impact on condom use has been discussed in a number of research studies (Rao et al. 2003; Gertler et al. 2005; Willman 2008, 2010; Adriaenssens \& Hendrickx 2012).

Once the debt has been paid off, the respondents generally join the ranks of autonomous female immigrants who rotate around the clubs under the plaza system. They also initiate a series of social and labour mobility strategies, renting their own homes (allowing them to rest better, obtain greater independence and eat a better diet than the women living clubs) or working in flats (which, as already mentioned, are associated with better health and hygiene, working and living conditions, and so on).

\section{Autonomous migration}

Half of the women interviewed emigrated independently to Spain, using money they had accumulated in their own country by taking out a bank loan, mortgaging their properties, resorting to a private moneylender or borrowing (on an interest-free basis) from family members or friends who had already emigrated. This, together with the fact that they are not under pressure to repay a debt, allows them access to better health, working and living conditions. This absence of financial - and by extension - personal pressure, means that the women can choose when and where they wish to offer their services. Independent workers therefore tend to move from business to business in accordance with demand and the job situation, the risk of police raids and working conditions (the treatment they received from the business owners, housing conditions and the standard of the food).

Independent immigrants can also decide whether they wish to accept a client, thereby choosing their rest periods. The health and hygiene conditions they work under are also better, as, for example, they can refuse customers who do not want to use a condom. Resisting the temptation to accept large sums of money from clients demanding 'risky sex' is easier when not under financial pressure, and therefore they are less vulnerable to sexually transmitted diseases and HIV than female migrants with a debt to repay. Furthermore, independence enables them to opt for alternative forms of work, such as in-call flats, where, as already pointed out, the working conditions are more favourable.

Nevertheless, the need and desire to accumulate funds (for example, for savings or sending remittances to family members in the country of origin), drives many independent sex workers 
to keep up this intense pace of work and to continue working under the plaza system of rotating around clubs, as will be shown below.

\section{Migratory projects and sex work strategies}

As the breadwinner in a transnational household, there is also pressure on the migrant woman not just to send money to ensure basic survival, but also to satisfy the family's consumer aspirations. Thus, some of the respondents in the study spoke in colloquial terms of their little macarras, this time referring not to a parasitic pimp, but to demanding children, brothers or sisters, or family members in general, asking for money to buy branded clothes or footwear, skateboards, or other products that reflect social success and standing.

\footnotetext{
I have two brothers and a daughter. I don't have a father, and my mother had a car crash and is in a wheelchair or walks with crutches. They're always asking me for money. My younger brother is the worst: now he wants a PlayStation, and the other one wants a motorbike. They think money grows on trees here. They don't realise what I have to go through to earn it. They don't know how I earn a living. My mum does, but my brothers don't. I feel like telling them, just to get them to stop asking me for money. I wish a man would appear for me to fuck! I need the money. (Colombian woman)
}

The decision to take one type of work or another (and by consequence the quality of work of Latin American women) is also determined by women's life and social mobility strategies, as linked to their migratory project. The fieldwork results reveal the presence of two main types of migratory projects among migrant female sex workers in Galicia: those who focus on achieving their goals and social mobility in the country of origin and those who invest in improving their social mobility in Spain.

Social mobility strategies targeting the country of origin tend to be associated with an additional, savings-based strategy. Women see migration as a 'temporary sacrifice' that consists of earning as much money as possible in the shortest possible time (leaving their husbands/partners and/or children behind in the country of origin) in order to be able to return to their countries of origin, where supposedly they will reap the benefits of their planned social mobility. In the majority of cases the migration project is of a family nature.

The savings strategy consists mainly of sex work whilst living in and moving from club to club under the plaza system. As has been shown, the club provides a series of advantages for those women migrants with a migratory project based on saving and return. Firstly, it enables them to make a considerable amount of money in a relatively short period of time, thereby making it easier for them to save. Secondly, it provides them with board and lodging, and eliminates the cost and difficulty of renting a flat (which requires valid documents and permits), the need to buy food, and so on.

Living in a club is cheaper, because you pay a fixed amount for your board and lodging. If you live outside you have to pay rent on a flat, as well as for your food and transport, and it works out more expensive [...] When you live in a club, you spend most of your time in the bar, so you save more. My sister and I get up and go straight to work, and we go to bed as soon as we get back. We don't get up until it's time to go to work, as that way we don't spend any money and the time seems to go quicker. When we lived in the flat we had a lot of expenses; you had to pay for this and that, and because there was shop opposite where we were living, we were always popping out to buy something. So in the end you hardly save at all. But living in the club is different; you know you've got your food and everything, so you save more. (Colombian woman working in a club in Galicia) 
Women with a social mobility strategy targeting the host social space, whose objective is to regroup their family and settle in Spain, tend to be less obsessed with the idea of saving and therefore deploy labour and residential strategies aimed at improving their living conditions, including working in flats. Therefore, the in-call flat is a common occupational strategy for female respondents in Galicia who have a more settled lifestyle. They live in a permanent residence, have reunited with their children or have a stable personal relationship. They may also have another job outside sex work and use the apartment as a means of earning extra income. The principal interest of these women does not lie in earning as much as possible in the shortest period of time, as is the case for women who travel to stay for a limited period of time in order to save as much as they can. The informants working in apartments wish to lead a more comfortable lifestyle with better working conditions, in a working environment that lessens the sense of stigma, even though this may mean a reduction in earnings. Consequently, in-call flats are associated, more than clubs, with a strategy aimed at social integration and mobility in Spain. The earnings are lower, but the emotional and social stability, as well as the working conditions, are better for women working in in-call flats, enabling them to separate their personal and working lives, due to the division between their private and work spaces.

It is therefore evident that the choice of employment type (clubs or in-call flats) is also conditioned by the sex workers' migratory and social mobility strategies. Working in flats is more suitable for women whose social mobility and settlement strategies are centred in Spain, in contrast to those who wish to save up as much money as possible for an early return to their country of origin. Thus, the study reveals how not only the structural factors and the entry mechanisms, but also the family social mobility strategies of migrant sex workers (that condition their choice of the type of employment) shed light on variations in the quality of the working and living conditions of Latin American female sex workers in Galicia.

\section{Conclusions}

This article has shown the difference in working and living conditions between the two principal types of sex work in Galicia (clubs and in-call flats). It has also identified the principal dimensions of work associated with this sector (wages, power relations, skills, alienation, health, violence, work life and stigma). Work in clubs, especially under the plaza system, has emerged as the type of work offering the harshest working and living conditions, characterised by greater submission and alienation of the workers, coupled with greater health risks, violence and stigma, thereby reducing women's possibilities of leading a settled family life. However, the earnings are higher, boosting their saving capacity. In contrast, the use of in-call flats is a form of sex work that generates lower earnings but offers better working and living conditions (greater autonomy, a lower degree of dependence, better health and hygiene conditions, as well as less violence and a lower sense of stigma). This type of employment allows women to lead a 'double life' and is also compatible with family life. The quality of life and work for sex workers in Galicia is therefore determined to a considerable extent by the type of sex work chosen by women (clubs and the plaza system or in-call flats). However, it is also conditioned by structural factors and by entry mechanisms to Spain (indebted or autonomous migration). Spain's policies on migration and sex work have led to a large number of undocumented female immigrants and considerable deterioration of the working and living conditions of these women, as well as that of those who are pushed to incur a debt in order to 
travel to Spain. These undocumented and indebted women are therefore exposed to greater health risks, as well as increased violence and relations with the owners of sex work businesses and moneylenders, as characterised by dependence and submission.

Finally, the living conditions of Latin American female migrants in Galicia are closely linked to the choices made by the sex workers themselves in relation to their migratory and social mobility projects. These projects are often of a collective nature and include maintaining the transnational household, or are designed to accumulate considerable financial resources in the shortest possible time (a savings and return project). This would explain why Latin American women choose to work in clubs under the plaza system, even if the working and living conditions are far worse. They see it as a 'temporary' sacrifice that will enable them to achieve their migratory and social mobility goals, based on accumulating financial resources and returning to their country of origin. In contrast, other women who wish to settle in Spain and are not under pressure to send remittances or who do not wish to reunite with their families, can deploy strategies aimed at improving their working and living conditions (renting a flat to live in whilst they work in the clubs, thereby providing greater independence, or opting for incall flats, which offer better working and living conditions). Their intention is to secure their upward social mobility in Spain, even though this may have a negative impact on their earnings, and thereby their saving capacity.

In short, on the one hand, structural considerations and entry mechanisms (undocumented or indebted women, in contrast to independent, documented female immigrants) explain variations in the working and living conditions experienced by Latin American female sex workers in Spain. On the other hand, the migratory and social mobility strategies of the social actors (projects based on saving and return or settlement) help us to understand the decisions women sex workers might make concerning the acceptance of one type of work or another (clubs or in-call flats). Thus, migrant women have to overcome the numerous hurdles Spain's restrictive policies on migration and sex work place in their way (restrictive migratory policy and no regulation of sex work, leading women to work in the informal economy), yet at the same time, they take decisions regarding their work and life strategies (acceptance of better or harsher type of work) based on their personal migratory and social mobility projects.

\section{Acknowledgments}

This research work, as well as the English editing of the text, was funded by the following research projects: "Gender, Transnationalism and inter-generational strategies of social mobility" (FEM2011-26110, Oso, dir. 2011) and "Gender Crossed Mobilities and Transnational Dynamics" (FEM2015-67164-R, Oso, dir. 2015), financed by the Spanish Ministry of Economy and Competitiveness. As well as the financial aid by the Xunta de Galicia: Programa de Consolidación e Estructuración de Unidades de investigación competitivas do Sistema Universitario de Galicia GRC2014/048 (Oso, dir. 2014-2017) The theoretical discussion on social mobility and migration of this paper is part of the authors' work within the context of INCASI (the International Network for Comparative Analysis of Social Inequalities), a European project financed by the Horizon 2020 programme (RISE action, GA 691004, 
http://cordis.europa.eu/project/rcn/200034_en.html) coordinated by Pedro López-Roldán (Autonomous University of Barcelona)

\section{References}

ADRIAENSSENS, S. and HENDRICKX, J. (2016) 'What can internet data tell about safe work? Unsafe sex and contract breach as proxies of quality of work in prostitution', Paper presented at Comparing European Prostitution Policies: Understanding Scales and Cultures of Governance (ProsPol) - Cost Action Meeting, Ljubljana, Slovenia, 21-23 March 2016.

ADRIAENSSENS, S. and HENDRICKX, J. (2012) 'Sex, price and preferences: Accounting for unsafe sexual practices in prostitution markets', Sociology of Health \& Illness, Vol. 34, Issue 5, p. 665680.

AGUSTíN, L. (2005) 'Migrants in the Mistress's house: Other voices in the trafficking debate,' Social Politics, Vol. 12, Issue 1, p. 96-117.

AGUSTín, L. (2007) Sex at the Margins: Migration, Labour Markets and the Rescue Industry. London: Zed Books.

BERNSTEIN, E. (2008) 'Sexual commerce and the global flow of bodies, desires, and social policies',Sexuality Research and Social Policy, Vol.5, Issue 4.

CABEZAS, A. (2009) Economies of Desire: Sex and Tourism in Cuba and the Dominican Republic. Philadelphia, PA: Temple University Press.

DAY, S. (2009) 'Renewing the war on prostitution: The spectres of "trafficking" and "slavery",Anthropology Today, Vol. 25, Issue 3, p.1-3.

DOEZEMA, J. (1998) Forced to choose: Beyond the voluntary v. forced prostitution dichotomy in Kempadoo, K. and Doezema, J. (Eds.) Global Sex Workers: Rights, Resistance and Redefinition. New York and London: Routledge.

FARR, K. (2005) Sex Trafficking: The Global Market in Women and Children. New York: Worth Publishers.

GERTLER, P. and BERTOZZI, S. M. (2005) 'Risky business: The market for unprotected commercial sex', Journal of Political Economy, Vol. 113, Issue 3, p. 518-550.

IOM (1995) Trafficking and Prostitution: The Growing Sexual Exploitation of Migrant Women from Central and Eastern Europe. International Organization for Migration.

IOM (1996) Trafficking in Women from the Dominican Republic for Sexual Exploitation, International Organization for Migration.

LIM, L. L. (Ed.) (1998) The sex sector: The economic and social bases of prostitution in Southeast Asia, International Labour Organization. 
LÓPEZ RIOPEDE, J. (2013) 'Transnational sex work: Implications of criminalizing prostitution policy and the Spanish economic crisis on migrant sex workers', Paper presented at XI Congreso Español de Sociología, FES, 10-12 July, Universidad Complutense de Madrid.

LÓPEZ RIOPEDRE, J. (2015) Mujeres Cruzando el Atlántico: Relatos Biográficos de Migrantes Brasileñas en los Mercados del Sexo. Granada: Editorial Comares.

MAl, N. (2001) Transforming traditions: A critical analysis of the trafficking and exploitation of Albanian girls in Italy in King, R. (Ed.) The Mediterranean Passage: Migration and New Cultural Encounters in Southern Europe. Liverpool: Liverpool University Press.

MCGRATH-LONE, L., MARSH, K., HUGHES, G. and WARD, H. (2014) 'The sexual health of female sex workers compared with other women in England: Analysis of cross-sectional data from genitourinary medicine clinics', Sexually Transmitted Infections, Vol 90, Issue 4, p. 344-350.

MUÑOZ DE BUSTILLO, R., FERNÁNDEZ-MACÍAS, E., ESTEVE, F. and ANTÓN, J. I. (2011) 'E pluribus unum? A critical survey of job quality indicators', Socio- Economic Review, Vol. 9, p. 447-475.

OSO, L. (2000) 'Estrategias migratorias y de movilidad social de las mujeres ecuatorianas y colombianas en situación irregular: servicio doméstico y prostitución' in IZQUIERDO, A. (dir.) Mujeres inmigrantes en la irregularidad. Pobreza, marginación laboral y prostitución. Madrid: Instituto de la Mujer.

OSO CASAS, L., ULLOA JIMÉNEZ, M. (2001a) 'Tráfico e inmigración femenina desde la voz de las mujeres inmigrantes", in Tráfico e Inmigración de Mujeres en España. Colombianas y Ecuatorianas en los servicios domésticos y sexuales, Informe de investigación. Asociación ACSUR-Las Segovias, ISBN: 84- 95039-07-9.

OSO, L. (2001b) 'Domestiques, concierges et prostituées: migration et mobilité sociale des femmes immigrées, espagnoles àParis, équatoriennes et colombiennes en Espagne' Thèse de Doctorat. IEDES-Université de Paris I-Panthéon Sorbonne. Directeur: Bruno Lautier.

OSO CASAS, L. (2003) 'Colombian and Ecuadorian women's migratory strategies' in FREEDMAN J., POKU, N. K. Gender and Insecurity. Migrant women in Europe. Aldershot: Ashgate.

PLAMBECH, S. (2014) 'Between victims and criminals: Nigerian migrant sex workers and the politics of rescue', Social Politics: International Studies in Gender, State and Society,Vol. 22, Issue 2.

PISCITELLI, A. (2013) Trânsitos: Brasileiras nos Mercados Transnacionais do Sexo. Rio de Janeiro: Universidade Estatal do Rio de Janeiro.

PISCITELLI, A. (2008) 'Entre as "mafias" e a "ajuda": A construcçao de cohecimento sobre tráfico de pessoas,' Cuadernos Pagu, Vol. 31, p. 9-28.

PRÜSS-USTÜN, A., WOLF, J., DRISCOLL, T., DEGENHARDT, L., NEIRA, M., and CALLEJA, J. M. G. (2013) 'HIV due to female sex work', Regional and Global Estimates. PLoS ONE, Vol. 8, Issue 5. 
RAO, V., GUPTA, I., LOKSHIN, M., and JANA, S. (2003) 'Sex workers and the cost of safe sex: The compensating differential for condom use in Calcutta', Journal of Development Economics, Vol. 40, p. 585-603.

SASSEN, S. (2003) 'The feminisation of survival: Alternative global circuits' in MorokvasicMüller, M., Erel, U. and Shinozaki, K. (Eds.) Crossing Borders and Shifting Boundaries, Vol. I: On the Move. Opladen: Leske+budrich.

SKROBANEK, S., BOONPAKDI, N. and JANTHAKEERO, C. (1997)The Traffic in Women: Human Realities of the International Sex Trade. London and New York: Zed Books.

SPANGER, M. (2010) 'Destabilising sex work and intimacy? Gender performances of female Thai migrants selling sex in Denmark', Ph.D.-afhandling, Roskilde Universitet.

STONE, A. and VANDENBERG, M. (1999) 'How the sex trade becomes a slave trade: The trafficking of women to Israel, Middle East' Report, No. 211, Trafficking and Transiting: New Perspectives on Labor Migration.

TONY AVIRGAN, L., BIVENS, J. and GAMMAGE, S. (Eds.) (2005) Good Jobs, Bad Jobs, No Jobs: Labor Markets and Informal Work in Egypt, El Salvador, India, Russia and South Africa. Washington, Economic Policy Institute.

WEITZER, R. (2007) 'The social construction of sex trafficking: Ideology and institutionalisation of a moral crusade', Politics and Society, Vol. 35, Issue 3, p. 447-475.

WILLMAN, A. (2008) 'Safety first, then condoms: Commercial sex, risky behavior, and the spread of HIV/AIDS in Managua, Nicaragua', Feminist Economics, Vol. 14, Issue 4, p. 37-65.

WILLMAN, A. (2010) 'Risk and reward in Managua's commercial sex market: The importance of workplace', Journal of Human Development and Capabilities, Vol. 11, Issue 4, p.503-531 